\title{
PENGARUH AKTIVITAS FISIK DAN OBESITAS DENGAN KEJADIAN HIPERTENSI PADA LANSIA DI PUSKESMAS KLAMPIS NGASEM KOTA SURABAYA
}

\author{
THE EFFECT OF PHYSICAL ACTIVITY AND OBESITY WITH THE EVENT OF \\ HYPERTENSION IN THE ELDERLY AT KLAMPIS PUSKESMAS NGASEM CITY SURABAYA
}

\author{
Novera Herdiani ${ }^{*}$, Mursyidul Ibad2 ${ }^{2}$ Edza Aria Wikurendra ${ }^{3}$, Naila Mafaza Ahsana4, Vena \\ Alifia Nurfirda ${ }^{5}$ \\ 1,2,3,4,5 Universitas Nahdlatul Ulama Surabaya \\ Kampus B Jl. Raya Jemursari No. 51-57 Surabaya \\ *Email : novera.herdiani@unusa.ac.id
}

\begin{abstract}
Hypertension is one of the non-communicable diseases that is an important health problem worldwide because of its high prevalence. The elderly are at high risk for degenerative diseases, namely hypertension. This study aims to analyze the effect of physical activity and obesity with the incidence of hypertension in the elderly at Klampis Ngasem Public Health Center, Surabaya. This research design uses a case control approach. The population is 106 elderly. The sample size is 84 elderly with 42 case groups and 42 control groups. The sampling technique used is simple random sampling. The multivariate analysis used in this study was logistic regression. The results showed that the elderly who had less physical activity were 16.562 times more likely to have hypertension with a $p$-value of $0.002<0.05$ ( $a O R=16.562 ; 95 \% C I=2.765-99.198)$. Elderly with obesity status (BMI $25.00 \mathrm{~kg} / \mathrm{m} 2)$ have a 3.595 times greater risk of developing hypertension than non-obese elderly, where $p$-value is $0.042<0.05(a O R=3.59595 \% C I=1.049-12.316)$. The conclusion in this study is that lack of physical activity and obesity are risk factors for hypertension in the elderly. It is expected that the elderly will routinely carry out health checks in health services so that blood pressure is controlled, and it is hoped that they will improve a healthy lifestyle such as maintaining an ideal body weight, and doing sufficient physical activity.
\end{abstract}

Keywords: elderly; hypertension; obesity; physical activity

\begin{abstract}
ABSTRAK
Hipertensi merupakan salah satu penyakit tidak menular yang menjadi masalah kesehatan penting di seluruh dunia karena prevalensinya yang tinggi. Lansia beresiko tinggi terhadap penyakit degeneratif yaitu hipertensi. Penelitian ini bertujuan untuk menganalisis pengaruh aktifitas fisik dan obesitas dengan kejadian hipertensi pada lansia di Puskesmas Klampis Ngasem Kota Surabaya. Desain penelitian ini menggnakan pendekatan case control. Populasi sebesar 106 lansia. Besar sampel yang diambil yaitu 84 lansia dengan 42 kelompok kasus dan 42 kelompok control. Teknik sampling yang digunakan simple random sampling. Analisis multivariat yang digunakan dalam penelitian ini adalah regresi logistik. Hasil penelitian menunjukkan bahwa lansia yang memiliki aktivitas fisik yang kurang berisiko 16,562 kali lebih besar untuk mengalami kejadian hipertensi dengan $p$-value 0,002 <0,05 (aOR = 16,562; $95 \% \mathrm{CI}=2,765-99,198)$. Lansia dengan status obesitas (IMT $\geq 25,00 \mathrm{~kg} / \mathrm{m}^{2}$ ) berisiko 3,595 kali lebih besar untuk mengalami kejadian hipertensi dibanding dengan lansia tidak obesitas, dimana $p$-value $0,042<0,05(\mathrm{aOR}=3,59595 \% \mathrm{CI}=1,049-12,316)$. Simpulan pada penelitian ini yaitu aktivitas fisik kurang dan obesitas menjadi faktor risiko kejadian hipertensi pada lansia. Diharapkan lansia untuk rutin melakukan pemeriksaan kesehatan di pelayanan kesehatan agar tekanan darah tetap terkontrol, serta diharapkan agar meningkatkan gaya hidup sehat seperti menjaga berat badan yang ideal, dan melakukan aktivitas fisik yang cukup.
\end{abstract}

Kata Kunci: lansia; hipertensi; obesitas; aktifitas fisik 


\section{PENDAHULUAN}

Hipertensi atau tekanan darah tinggi adalah peningkatan tekanan darah sistolik lebih dari 140 $\mathrm{mmHg}$ dan tekanan darah diastolik lebih dari 90 mmHg pada dua kali pengukuran dengan selang waktu lima menit dalam keadaan cukup istirahat/tenang. Hipertensi banyak terjadi pada umur 35-44 tahun (6,3\%), umur 45-54 tahun (11,9\%), dan umur 55-64 tahun (17,2\%) (1). Menurut Organisasi Kesehatan Dunia (WHO), lansia (lanjut usia) adalah usia yang meliputi usia pertengahan (4559 tahun), usia lanjut (60-74 tahun), usia lanjut tua (75-90 tahun) dan usia sangat tua (diatas 90 tahun) (2). Salah satu penyakit yang banyak di derita oleh lansia yaitu hipertensi (3). Berdasarkan Riskesdas tahun 2018 prevalensi hipertensi menurut hasil pengukuran pada penduduk usia $\geq 18$ tahun di Indonesia adalah sebesar 34,1\% (1). Dinas Kesehatan Kota Surabaya tahun 2020 melaporkan sebanyak 399.435 jiwa $(31,13 \%)$ yang menderita hipertensi dari total penduduk 2.266.847 jiwa yang berumur $\geq 18$ tahun yang melakukan pengukuran tekanan darah di Puskesmas. Wilayah kerja puskesmas di Surabaya yang memiliki kasus hipertensi yang tinggi salah satunya yaitu Puskesmas Klampis Ngasem sebesar 93,99\%. Prevalensi hipertensi di wilayah kerja Puskesmas Ngasem meningkat secara signifikan, yaitu sebesar 31,58\% pada tahun 2019 menjadi 93,99\% pada tahun 2020 (4).

Menurut (5) saat ini terdapat kecenderungan pada masyarakat perkotaan lebih banyak menderita hipertensi dibandingkan masyarakat pedesaan. Hal ini antara lain dihubungkan dengan adanya gaya hidup masyarakat kota yang berhubungan dengan risiko hipertensi seperti obesitas (kegemukan) dan kurangnya aktivitas fisik. Perubahan gaya hidup seperti perubahan pola makan menjurus ke sajian siap santap yang mengandung banyak lemak, protein, dan tinggi garam tetapi rendah serat pangan, membawa konsekuensi sebagai salah satu faktor berkembangnya penyakit degeneratif seperti hipertensi (6). Perkembangan hipertensi dipengaruhi oleh banyak faktor dimana salah satunya adalah aktifitas fisik. Orang yang dengan aktifitas fisik kurang tapi dengan nafsu makan yang kurang terkontrol sehingga terjadi konsumsi energi yang berlebihan mengakibatkan nafsu makan bertambah yang akhirnya berat badannya naik dan dapat menyebabkan obesitas (7). Jika berat badan seseorang bertambah, maka volume darah akan bertambah pula, sehingga beban jantung untuk memompa darah juga bertambah kemudian menimbulkan hipertensi (8).

Faktor lain yang menyebabkan hipertensi adalah obesitas. Obesitas merupakan keadaan kelebihan berat badan sebesar 20\% atau lebih dari berat badan ideal. Obesitas mempunyai korelasi positif dengan hipertensi. Ada dugaan bahwa meningkatnya berat badan normal relatif sebesar $10 \%$ mengakibatkan kenaikan tekanan darah $7 \mathrm{mmHg}$ (9). Menurut penelitian yang dilakukan oleh Sapitri tahun 2016 menunjukkan bahwa orang dengan obesitas (IMT > 25) beresiko menderita hipertensi sebesar 6,47 kali dibanding dengan orang yang tidak obesitas (10). Indeks Massa Tubuh (IMT) sebagai indeks sederhana dari berat badan terhadap tinggi badan yang digunakan untuk mengklasifikasikan kelebihan berat badan dan obesitas, perhitungan IMT didefinisikan sebagai berat badan dalam kilogram dibagi dengan tinggi badan dalam meter $\left(\mathrm{kg} / \mathrm{m}^{2}\right)(1)$.

Penelitian tentang penyakit hipertensi pada lansia di Puskesmas Klampis Ngasem Kota Surabaya belum pernah dilakukan sebelumnya dan angka kejadian hipertensi pada lansia masih tinggi. Sehingga peneliti tertarik untuk melakukan penelitian tentang faktor yang mempengaruhi kejadian hipertensi yaitu pengaruh aktivitas fisik dan obesitas dengan kejadian hipertensi pada lansia di Puskesmas Klampis Ngasem Kota Surabaya.

\section{BAHAN DAN METODE}

Desain penelitian yang digunakan dalam penelitian ini adalah kasus kontrol (case control). Populasi dalam penelitian ini yaitu seluruh lansia yang memeriksakan kesehatannya di Puskesmas Klampis Ngasem Kota Surabaya pada tahun 2021 sejumlah 106 lansia. Pada penelitian pengaruh aktifitas fisik dan obesitas dengan kejadian penyakit hipertensi pada lansia, ada dua sampel pada penelitian ini yaitu kelompok kasus pada lansia yang menderita penyakit hipertensi baru maupun riwayat hipertensi sebelumnya dan kelompok kontrol pada lansia yang tidak menderita penyakit hipertensi. Penentuan besarnya sampel penelitian dengan memperhatikan Odds Ratio hasil beberapa penelitian terdahulu tentang beberapa faktor risiko hipertensi dengan jumlah 42 lansia kasus dan 42 lansia kontrol. 
Cara pengambilan sampel yang digunakan dalam penelitian ini adalah simple random sampling. Penelitian ini dilaksanakan di Puskesmas Klampis Ngasem Kota Surabaya.

Teknik pengumpulan data pada penelitian ini menggunakan data primer diperoleh dari pengisian kuesioner oleh responden secara online dan offline. Analisis univariat dilakukan secara deskriptif terhadap variabel yang diteliti yaitu variabel aktivitas fisik dan obesitas pada lansia di Puskesmas Klampis Ngasem Kota Surabaya. Data hasil dari penelitian tersebut dideskripsikan dalam bentuk tabel dan narasi untuk mengevaluasi besarnya proporsi masing-masing. Interpretasi data menggunakan skala kualitatif. Analisis bivariat yang dilakukan terhadap dua variabel yang diduga berhubungan atau berkorelasi dan mengetahui yang paling berpengaruh dengan regresi logistik. Analisis ini digunakan untuk mengetahui hubungan antara masing-masing variabel independen dengan variabel dependen. Uji statistik yang digunakan pada penelitian ini yaitu uji chi square dan selanjutnya yang digunakan dalam penelitian ini adalah regresi logistik.

\section{HASIL DAN PEMBAHASAN}

\section{Analisis Univariat}

Analisis univariat dalam penelitian ini meliputi aktifitas fisik dann obesitas. Informasi disajikan dalam tabel 1.

Tabel 1. Distribusi Frekuensi Berdasarkan Aktivitas Fisik dan Obesitas Hipertensi Pada Lansia di Puskesmas Klampis Ngasem Kota Surabaya.

\begin{tabular}{lcc}
\hline \multicolumn{1}{c}{ Variabel } & n & \% \\
\hline Aktivitas fisik & & \\
Kurang & 61 & 72,6 \\
Cukup & 23 & 27,4 \\
Obesitas & & \\
Obesitas & 50 & 59,5 \\
Tidak Obesitas & 34 & 40,5 \\
\hline Total & $\mathbf{8 4}$ & $\mathbf{1 0 0 , 0}$ \\
\hline
\end{tabular}

Berdasarkan tabel 1, dapat diinformasikan bahwa sebagian besar responden $(72,6 \%)$ memiliki aktivitas fisik yang kurang. Untuk variabel obesitas menunjukkan bahwa sebagian besar responden $(59,5 \%)$ termasuk dalam kategori obesitas

\section{Analisis Bivariat}

Tabel 2. Hubungan Aktivitas Fisik dengan Kejadian Hipertensi Pada Lansia di Puskesmas Klampis Ngasem Kota Surabaya

\begin{tabular}{|c|c|c|c|c|c|c|c|c|c|}
\hline \multirow{3}{*}{ Variabel } & \multicolumn{4}{|c|}{ Hipertensi } & \multirow{2}{*}{\multicolumn{2}{|c|}{ Total }} & \multirow[t]{3}{*}{ OR } & \multirow[t]{3}{*}{$95 \% \mathrm{CI}$} & \multirow[t]{3}{*}{ P-Value } \\
\hline & \multicolumn{2}{|c|}{ Kasus } & \multicolumn{2}{|c|}{ Kontrol } & & & & & \\
\hline & $\mathbf{n}$ & $\%$ & $\mathbf{n}$ & $\%$ & $\mathrm{n}$ & $\%$ & & & \\
\hline \multicolumn{10}{|l|}{ Aktifitas } \\
\hline \multicolumn{10}{|l|}{ Fisik } \\
\hline Kurang & 40 & 65,6 & 21 & 34,4 & 61 & 100,0 & 20,000 & $4,272-93,626$ & 0,000 \\
\hline Cukup & 2 & 8,7 & 21 & 91,3 & 23 & 100,0 & & & \\
\hline \multicolumn{10}{|l|}{ Obesitas } \\
\hline Obesitas & 34 & 68,0 & 16 & 32,0 & 50 & 100,0 & 6,906 & $2,565-18,595$ & 0,000 \\
\hline Tidak & 8 & 23,5 & 26 & 76,5 & 34 & 100,0 & & & \\
\hline Obesitas & & & & & & & & & \\
\hline
\end{tabular}

Berdasarkan tabel 2, dapat diinformasikan bahwa persentase responden yang aktivitas fisik kurang lebih banyak pada kelompok kasus $(65,6 \%)$ daripada kelompok kontrol (34,4\%). Hasil uji chi square didapatkan $P$-Value sebesar $0,000<0,05$ yang berarti $\mathrm{H}_{1}$ diterima, artinya ada hubungan antara aktivitas fisik dengan kejadian hipertensi pada lansia di Puskesmas Klampis Ngasem Kota Surabaya.
Sedangkan persentase responden obesitas lebih banyak pada kelompok kasus $(68,0 \%)$ daripada kelompok kontrol (32,0\%). Hasil uji chi square didapatkan $P$-Value sebesar 0,000 $<0,05$ yang berarti $\mathrm{H}_{1}$ diterima, artinya ada hubungan antara obesitas dengan kejadian hipertensi pada lansia di Puskesmas Klampis Ngasem Kota Surabaya. 
Berdasarkan hasil uji chi square menunjukkan bahwa $P$-Value $0,000<0,05$ artinya ada hubungan antara aktivitas fisik dengan kejadian hipertensi pada lansia di Puskesmas Klampis Ngasem Kota Surabaya. Lansia yang memiliki aktivitas fisik yang kurang berisiko mengalami hipertensi sebesar 20,00 kali lebih besar dibandingkan dengan lansia yang melakukan aktivitas fisik yang cukup (95\% CI $=4,272-93,626)$. Hasil uji chi square menunjukkan bahwa P-Value 0,000 $<0,05$ artinya ada hubungan antara obesitas dengan kejadian hipertensi pada lansia di Puskesmas Klampis Ngasem Kota Surabaya. Lansia dengan status obesitas berisiko mengalami hipertensi sebesar 6,906 kali lebih besar dibandingkan dengan lansia tidak obesitas ( $95 \% \mathrm{CI}=2,565-18,595)$.

\section{Analisis Multivariat}

Variabel yang menjadi kandidat model multivariat adalah variabel independen dengan $P$ Value $<0,25$. Variabel-variabel yang masuk ke dalam model multivariat dapat dilihat pada tabel berikut:

Tabel 3. Rangkuman Hasil Analisis Regresi Logistik Sederhana

\begin{tabular}{lccc}
\hline Variabel & OR & 95\% CI & P-Value \\
\hline Obesitas & 6,906 & $2,565-18,595$ & 0,000 \\
Aktivitas & 20,000 & $4,272-93,626$ & 0,000 \\
Fisik & & & \\
\hline
\end{tabular}

Berdasarkan Tabel 3, dapat diinformasikan bahwa dari hasil analisis regresi logistik sederhana maka variabel dengan $P$-Value $<0,25$ yang masuk ke dalam model multivariat yaitu variabel obesitas, dan aktivitas fisik. Kemudian dilakukan analisis regresi logistik ganda dengan metode enter, yaitu memasukkan semua variabel independen ke dalam model, tetapi kemudian satu per satu variabel independen dikeluarkan dari model berdasarkan kriteria kemaknaan statistik tertentu. Variabel yang dapat masuk dalam model regresi logistik adalah variabel yang mempunyai $P$-Value $<0,05$. Hasil analisis regresi logistik multivariat dapat dilihat pada tabel berikut:
Tabel 4. Variabel yang Berhubungan dengan Kejadian Hipertensi pada Lansia di Puskesmas Klampis Ngasem Kota Surabaya

\begin{tabular}{lcccc}
\hline Variabel & Nilai B & aOR & 95\% CI & $\begin{array}{l}\text { P- } \\
\text { Value }\end{array}$ \\
\hline Aktivitas & 2,807 & \multirow{2}{*}{16,562} & $\begin{array}{l}2,765- \\
99,198\end{array}$ & 0,002 \\
Fisik & & & $\begin{array}{l}1,049- \\
12,316\end{array}$ & 0,042 \\
Obesitas & 1,280 & \multirow{2}{*}{3,595} \\
\hline
\end{tabular}

Berdasarkan Tabel 4, dapat diinformasikan bahwa setelah dilakukan analisis menggunakan uji regresi logistik multivariat dengan metode enter didapatkan hasi bahwa faktor risiko yang paling berpengaruh terhadap kejadian hipertensi pada lansia di Puskesmas Klampis Ngasem Kota Surabaya bahwa lansia yang memiliki aktivitas fisik yang kurang berisiko 16,562 kali lebih besar untuk mengalami kejadian hipertensi dibanding dengan lansia yang memiliki aktivitas fisik yang cukup, dimana $P$-Value 0,002 < 0,05 yang memiliki arti ada hubungan antara aktivitas fisk dengan kejadian hipertensi pada lansia di Puskesmas Klampis Ngasem Kota Surabaya dengan nilai (95\% CI $=2,765$ 99,198). Lansia dengan status obesitas (IMT $\geq 25,00$ $\mathrm{kg} / \mathrm{m} 2$ ) berisiko 3,595 kali lebih besar untuk mengalami kejadian hipertensi dibanding dengan lansia tidak obesitas, dimana P-Value 0,042 < 0,05 yang memiliki arti ada hubungan antara obesitas dengan kejadian hipertensi pada lansia di Puskesmas Klampis Ngasem Kota Surabaya dengan nilai (95\% $\mathrm{CI}=1,049-12,316)$.

Berdasarkan hasil uji chi square menunjukkan bahwa P-Value 0,000 <0,05 artinya ada hubungan antara aktivitas fisik dengan kejadian hipertensi pada lansia di Puskesmas Klampis Ngasem Kota Surabaya. Lansia yang memiliki aktivitas fisik yang kurang berisiko mengalami hipertensi sebesar 20,00 kali lebih besar dibandingkan dengan lansia yang melakukan aktivitas fisik yang cukup (95\% CI $=4,272-93,626)$. Sedangkan berdasarkan hasil uji regresi logistik menunjukkan bahwa $P$-Value 0,002 < 0,05 yang berarti ada hubungan antara aktivitas fisik dengan kejadian hipertensi pada lansia di Puskesmas Klampis Ngasem Kota Surabaya dengan nilai aOR = $16,562(95 \%$ CI $=2,765-99,198)$, sehingga dapat diartikan bahwa lansia yang memiliki aktivitas fisik 
yang kurang berisiko 16,562 kali lebih besar untuk mengalami kejadian hipertensi dibanding lansia yang memiliki aktivitas fisik yang cukup. Pada penelitian ini proporsi lansia yang memiliki aktivitas fisik yang kurang sebanyak $40(65,6 \%)$ lansia yang mengalami hipertensi, sedangkan sebanyak 21 (34,4\%) lansia yang tidak mengalami hipertensi. Faktor tersebut merupakan faktor risiko kejadian hipertensi pada lansia di Puskesmas Klampis Ngasem Kota Surabaya.

Penelitian ini sejalan dengan (11) yang menyatakan bahwa ada hubungan antara aktivitas fisik dengan kejadian hipertensi pada lansia dengan p-value 0,009 memiliki risiko hipertensi, dengan OR sebesar 3,625. Jadi, lansia yang memiliki aktivitas fisik yang kurang memiliki risiko sebesar 3,625 kali lebih besar daripada lansia yang yang aktivitasnya cukup. Hasil penelitian ini juga sejalan dengan (12) yang menyebutkan ada hubungan aktivitas fisik dengan kejadian hipertensi dengan p-value 0,04 dan OR sebesar 4,009, artinya orang yang memiliki aktivitas fisik kurang berisiko 4,009 kali lebih besar dibanding orang yang melakukan aktivitas fisik yang cukup.

Aktivitas fisik merupakan kebiasaan seseorang untuk melakukan kegiatan yang memerlukan sistem gerak, baik berupa pekerjaan fisik maupun olahraga. Olahraga merupakan suatu kebiasaan gaya hidup yang harus dimulai sejak dini hingga usia lanjut, agar di masa mendatang kesehatan dan kebugaran tubuh tetap terjaga serta tidak mudah terserang penyakit. Karena semakin tua tubuh seseorang secara otomatis daya tahan tubuhnya akan semakin menurun (13). Orang yang tidak aktif melakukan aktivitas fisik cenderung mempunyai frekuensi denyut jantung yang lebih tinggi sehingga otot jantungnya harus bekerja lebih keras pada setia kontraksi. Makin keras otot jantung harus memompa, makin besar tekanan yang dibebankan pada arteri sehingga tahanan perifer yang meningkat menyebabkan tekanan darah menjadi tinggi (14).

Berdasarkan hasil penelitian mengenai aktivitas fisik yang dilakukan oleh lansia meliputi aktivitas berat, sedang dan ringan. Mayoritas lansia melakukan aktivitas yang ringan dan tidak memerlukan waktu yang lama serta lebih banyak menghabiskan waktu luang dengan istirahat dan menontot TV. Selain itu, semenjak adanya pandemi covid-19 yang semulanya rutin diadakan senam lansia setiap minggu menjadi ditiadakan, sehingga membuat para lansia tidak rutin melakukan senam lagi. Berdasarkan hasil penelitian tersebut dapat disimpulkan bahwa mayoritas lansia memiliki aktivitas fisik yang kurang dari 600 MET. Aktivitas fisik kurang $(<600$ MET) menjadi faktor risiko kejadian hipertensi pada lansia di Puskesmas Klampis Ngasem Kota Surabaya.

Berdasarkan hasil uji chi square menunjukkan bahwa $P$-Value $0,000<0,05$ artinya ada hubungan antara obesitas dengan kejadian hipertensi pada lansia di Puskesmas Klampis Ngasem Kota Surabaya. Lansia dengan status obesitas berisiko mengalami hipertensi sebesar 6,906 kali lebih besar dibandingkan dengan lansia tidak obesitas $(95 \% \mathrm{CI}=$ 2,565-18,595). Sedangkan berdasarkan hasil uji regresi logistik menunjukkan bahwa P-Value 0,042 < 0,05 yang berarti ada hubungan obesitas dengan kejadian hipertensi pada lansia di Puskesmas Klampis Ngasem Kota Surabaya dengan nilai aOR $=3,595$ (95\% CI $=1,049-12,316)$, sehingga dapat diartikan bahwa lansia dengan status obesitas berisiko 3,595 kali lebih besar untuk mengalami kejadian hipertensi dibanding lansia yang tidak besitas. Pada penelitian ini proporsi lansia yang obesitas sebanyak $34(68,0 \%)$ lansia yang mengalami hipertensi, sedangkan sebanyak $16(32,0 \%)$ lansia yang tidak mengalami hipertensi. Faktor tersebut merupakan faktor risiko kejadian hipertensi pada lansia di Puskesmas Klampis Ngasem Kota Surabaya.

Penelitian ini sejalan dengan (15) yang menyatakan bahwa ada hubungan antara obesitas dengan kejadian hipertensi pada lansia dengan $p$ value 0,009 dan OR sebesar 6,7. Jadi, lansia obesitas memiliki risiko menderita hipertensi sebesar 6,7 kali lebih besar daripada lansia yang tidak obesitas. Hasil penelitian ini juga sejalan dengan Kartika \& Purwaningsih, (2020) yang menyebutkan bahwa ada hubungan obesitas dengan kejadian hipertensi dengan p-value 0,029 dan OR sebesar 2,53, artinya orang yang obesitas berisiko 2,53 kali lebih besar dibanding orang yang tidak obesitas.

Menurut (16) penyebab fundamental obesitas dan gemuk adalah keadaan energi yang tidak seimbang antara konsumsi kalori dan kalori yang dikeluarkan, meliputi asupan makanan tinggi lemak dan rendahnya aktivitas fisik seseorang. Obesitas dapat mengakibatkan terjadinya hipertensi dari 
berbagai mekanisme yakni secara langsung ataupun secara tidak langsung. Secara langsung obesitas dapat mengakibatkan meningkatnya cardiac output.

Hal ini dikarenakan semakin besarnya massa tubuh maka semakin banyak pula jumlah darah yang beredar dan ini menyebabkan curah jantung meningkat (18). Sedangkan secara tidak langsung, obesitas terjadi melalui perangsangan aktivitas sistem darah simpatis dan Renin Angiotensin Aldosteron System (RAAS) oleh mediator-mediator seperti sitokin, hormon, dan adipokin. Hormon aldosteron merupakan salah satu yang berkaitan erat dengan retensi air dan natrium yang dapat membuat volume darah akan meningkat (19). Seseorang yang mengalami obesitas atau memiliki berat badan berlebih akan membutuhkan lebih banyak darah untuk bekerja menyuplai makanan dan oksigen ke jaringan tubuh. Hal tersebut akan membuat volume darah yang beredar melalui pembuluh darah aka meningkat, kerja jantung meningkat dan ini yang menyebabkan tekanan darah juga akan ikut meningkat (20).

Hal ini didukung ketika peneliti melakukan wawancara dengan lansia mengenai status obesitas meliputi pola makan, aktivitas fisik lansia sehari-hari yang menyebabkan lansia tersebut obesitas. Karena kurangnya aktivitas fisik yang dilakukan oleh lansia sehingga kalori dan energi yang dikeluarkan lansia sedikit. Jika berat badan seseorang bertambah, volume darah akan bertambah pula, sehingga menyebabkan hipertensi. Berdasarkan hasil penelitian dapat disimpulkan bahwa aktifitas fisik yang kurang dan obesitas menjadi faktor risiko kejadian hipertensi pada lansia di Puskesmas Klampis Ngasem Kota Surabaya.

\section{KESIMPULAN DAN SARAN}

Berdasarkan hasil penelitian yang telah dilakukan dapat disimpulkan bahwa aktifitas fisik dan obesitas merupakan variabel yang menjadi faktor risiko kejadian hipertensi pada lansia di Puskesmas Klampis Ngasem Kota Surabaya. Disarankan untuk dilakukan penelitian lanjut untuk mengetahui faktor yang mempengaruhi kejadian hipertensi pada lansia dengan melihat faktor lain seperti stress dan riwayat penyakit.

\section{UCAPAN TERIMAKASIH}

Terimakasih pada Puskesmas Klampis Ngasem Kota Surabaya atas ijin penelitian dan juga pada Universitas Nahdlatul Ulama Surabaya atas support penelitian yang diberikan.

\section{DAFTAR PUSTAKA}

1. Kemenkes RI. Riset Kesehatan Dasar (RISKESDAS) 2018. Jakarta: Kementerian Kesehatan RI; 2018.

2. WHO. Global Target 6: A 25\% Relative Reduction in The Prevalence of Raised Blood Pressure or Contain The Prevalence of Raised Blood Pressure, According to National Circumstances. Jenewa: World Health Organization; 2016.

3. Van, N. B., Hoang, L. V., Van, T. B., Anh, H. N. S., Minh, H. T., Do Nam, K., \& Chu, D. T. Prevalence and risk factors of hypertension in the Vietnamese elderly. High Blood Pressure \& Cardiovascular Prevention. 2019;26(3):239-246.

4. Dinas Kesehatan Kota Surabaya. Profil Kesehatan Kota Surabaya 2020. Surabaya: Dinas Kesehatan Kota Surabaya; 2020.

5. Amu, D. A. Faktor-Faktor yang Berhubungan dengan Hipertensi di Wilayah Perkotaan dan Pedesaan Indonesia Tahun 2013 [Skripsi]. Jakarta: UIN Syarif Hidayatullah; 2016.

6. Arif, D., Rusnoto, R. \& Hartinah, D. FaktorFaktor yang Berhubungan dengan Kejadian Hipertensi pada Lansia di Pusling Desa Klumpit UPT Puskesmas Gribig Kabupaten Kudus. Jurnal Ilmu Keperawatan dan Kebidanan. 2013;4(2):18-33.

7. Shariq, O. A., \& McKenzie, T. J. Obesity-related hypertension: a review of pathophysiology, management, and the role of metabolic surgery. Gland surgery. 2010; 9(1):80.

8. Ariyanto, H., Malik, A. A., Widianti, W., \& Oktavia, W. Prevalence and Correlation of Knowledge Levels with the Physical Activity of Hypertension Patients. Genius Journal. 2020;1(2):45-49.

9. Budianto, A., Hariyanto, T. \& Adi, C. R. Hubungan Perilaku Merokok dan Minum Kopi dengan Tekanan Darah pada Laki-Laki Dewasa di Desa Kertosuko Kecamatan Krucil Kabupaten Probolinggo. Nursing News: Jurnal Ilmiah Keperawatan. 2017;2(2):11-21.

10. Sapitri, N., Suyanto, S. \& Butar-Butar, W. R. Analisis Faktor Risiko Kejadian Hipertensi pada 
Masyarakat di Pesisir Sungai Siak Kecamatan

Rumbai Kota Pekanbaru. Jurnal Jom FK. 2016;3(1):1-12.

11. Lailli, N. F. \& Restyana, A. Analisis Faktorfaktor yang mempengaruhi terjadinya Hipertensi pada pasien Lansia di Kelurahan Semampir Kota Kediri Tahun 2018. Java Health Journal. 2020;5(2):1-12.

12. Siregar, P. A. Analisis Faktor Risiko Kejadian Hipertensi Masyarakat Pesisir Kota Medan. Jurnal Pembangunan Perkotaan. 2020;8(1):1-8.

13. Akbar, H. Determinan Epidemiologi Kejadian Hipertensi pada Lansia di Wilayah Kerja Puskesmas Jatisawit. Jurnal Hibualamo: Seri Ilmu-Ilmu Alam dan Kesehatan. 2018;2(2):41-47.

14. Ernawati, I., Fandinata, S. S., \& Permatasari, S. N. Buku referensi: kepatuhan konsumsi obat pasien hipertensi: pengukuran dan cara meningkatkan kepatuhan. Gresik: Penerbit Graniti; 2020.

15. Pitriani, R., Yanti, J. S. \& Afni, R. Faktor-faktor yang Mempengaruhi Kejadian Hipertensi pada Lansia di Wilayah Kerja Puskesmas Rumbai Pesisir. Jurnal Penelitian Kesehatan Suara Forikes. 2018;9(1):74-77.

16. WHO. Obesity. Available at: http://www.who.int/obesity/en/; 2016.

17. Pouwels, S., Sanches, E. E., Topal, B., \& Celik, A. Cardiac, hemodynamic and electrophysiological changes in obesity and the effects of bariatric and metabolic surgery. In Biochemistry of Cardiovascular Dysfunction in Obesity (pp. 353365). Springer, Cham.

18. Mouton, A. J., Li, X., Hall, M. E., \& Hall, J. E. Obesity, hypertension, and cardiac dysfunction: novel roles of immunometabolism in macrophage activation and inflammation. Circulation research. 2020;126(6): 789-806.

19. Morimoto, S., \& Ichihara, A. Management of primary aldosteronism and mineralocorticoid receptor-associated hypertension. Hypertension Research. 2020;43(8):744-753.

20. Tiara, U. I. Hubungan Obesitas Dengan Kejadian Hipertensi. Journal of Health Science and Physiotherapy. 2020;2(2):167-171. 